\title{
Pengembangan Bahan Ajar Materi Pythagoras yang Berorientasi pada Kompetensi Abad 21 untuk Guru SMP
}

\author{
Ida Maryamah \\ Magister Pendidikan Matematika Pascasarjana, Universitas Sultan Ageng Tirtayasa, Serang, \\ Indonesia, Penulis Korespondensi, idamaryamah@gmail.com

\section{Nurul Anriani} \\ Magister Pendidikan Matematika Pascasarjana, Universitas Sultan Ageng Tirtayasa, Serang, \\ Indonesia,nurul_anriani@yahoo.co.id

\section{Maman Fathurrohman} \\ Magister Pendidikan Matematika Pascasarjana, Universitas Sultan Ageng Tirtayasa, Serang, \\ Indonesia, mamanf@untirta.ac.id
}

\begin{tabular}{l} 
Informasi Artikel \\
\hline Sejarah artikel: \\
Diterima 31 Oktober 2018 \\
Direvisi 16 November 2018 \\
Disetujui 19 November 2018
\end{tabular}

\section{Kata kunci:}

Bahan Ajar Matematika,

Teorema Pythagoras,

Kompetensi Abad 21

\begin{abstract}
ABSTRAK
Tujuan penelitian ini adalah untuk menghasilkan produk berupa buku ajar matematika yang berorientasi pada kompetensi abad 21 pada materi Pythagoras kelas VIII semester genap yang valid. Jenis penelitian ini merupakan penelitian pengembangan yang meliputi tujuh langkah pokok, yaitu: analisis kebutuhan, kemampuan peneliti sebagai pengembang, produk yang dikembangkan, konsep produk, pengembangan produk, uji ahli, dan uji coba lapangan. Hasil penelitian berupa buku ajar matematika yang berorientasi pada kompetensi abad 21 pada materi Pythagoras kelas VIII yang valid. Kevalidan buku ajar diperoleh berdasarkan data dari angket penilaian para ahli, yaitu ahli materi, ahli bahasa, dan ahli media. Penilaian ahli materi mencapai kategori baik, ahli bahasa mencapai kategori sangat baik, dan ahli media mencapai kategori sangat baik. Sedangkan keterbacaan dan kepraktisan buku ajar diperoleh dari data angket penilaian guru matematika yang hasilnya mencapai kategori sangat baik. Jadi dapat disimpulkan bahwa buku ajar matematika yang berorientasi pada kompetensi abad 21 pada materi Pythagoras layak digunakan dalam kegiatan pembelajaran matematika.
\end{abstract}

Copyright (C) 2019 by the authors; licensee Department of Mathematics Education, University of Singaperbangsa Karawang. All rights reserved.

This is an open access article distributed under the terms of the CC BY-SA license. (http://creativecommons.org/licenses/by-sa/4.0)

\section{PENDAHULUAN}

Matematika merupakan salah satu mata pelajaran wajib yang diajarkan pada setiap jenjang pendidikan yang ada di Indonesia, mulai dari Sekolah Dasar (SD), Sekolah Menengah Pertama (SMP), dan Sekolah Menengah Atas (SMA) atau Sekolah Menengah Kejuruan (SMK). Adapun tujuan diajarkannya matematika kepada siswa adalah agar siswa memiliki kemampuan logis, kritis, analitis, cermat dan teliti, bertanggung jawab, responsif, dan tidak mudah menyerah dalam memecahkan masalah (Mendikbud, 2016). Disebutkan pula bahwa matematika perlu diajarkan kepada siswa untuk membekali siswa agar memiliki sikap terbuka, objektif dalam interaksi kelompok maupun aktivitas sehari-hari, 
juga memiliki kemampuan mengkomunikasikan gagasan matematika dengan jelas. Dari beberapa tujuan tersebut, terdapat tujuan pembelajaran matematika berpikir tingkat tinggi yang dibutuhkan dalam kehidupan di abad 21.

Berbagai organisasi mencoba merumuskan berbagai macam kompetensi dan keterampilan yang diperlukan dalam menghadapi abad 21. Namun, satu hal penting yang perlu diperhatikan adalah bahwa mendidik generasi muda di abad 21 tidak bisa hanya dilakukan melalui satu pendekatan saja. Trilling \& Fadel (2009) mengidentifikasi kompetensi yang diperlukan di abad 21, yaitu kompetensi komunikasi (communication), kolaborasi (collaboration), berpikir kritis dan memecahkan masalah (critical thinking and problem solving), kreatif dan inovatif (creativity and innovation).

Salah satu komponen sistem pembelajaran yang memegang peranan penting dalam pencapaian Standar Kompetensi (SK) dan Kompetensi Dasar (KD) adalah buku ajar. (Susanto, 2013) mendefinisikan "buku ajar adalah buku yang disusun untuk mencapai tujuan pembelajaran atau kompetensi tertentu". Sedangkan (Khikmiyah \& Midjan, 2016) berpendapat "buku ajar merupakan bahan-bahan atau materi pembelajaran yang disusun secara sistematis yang digunakan guru dan siswa dalam proses pembelajaran".

Buku ajar yang tersusun secara sistematis akan mempermudah peserta didik dalam menerima materi sehingga mendukung ketercapaian tujuan pembelajaran. Maka dari itu, buku ajar harus disusun secara sistematis, menarik, aspek keterbacaan tinggi, mudah dicerna, dan mematuhi aturan penulisan yang berlaku (Susanto, 2013). Sehingga dengan adanya buku ajar kegiatan belajar mengajar di sekolah diharapkan menjadi lebih lancar dan efektif.

Bahan ajar yang berupa buku sangat penting artinya bagi guru dan siswa dalam proses pembelajaran di kelas. Sungkono (2009) memaparkan bahwa guru akan mengalami kesulitan dalam meningkatkan efektivitas pembelajarannya jika tanpa disertai bahan ajar yang lengkap. Begitu pula bagi siswa, tanpa adanya bahan ajar siswa akan mengalami kesulitan dalam belajarnya. Dengan demikian, pengembangan bahan ajar di sekolah perlu memperhatikan karakteristik siswa dan kebutuhan siswa sesuai kurikulum, yaitu menuntut adanya partisipasi dan aktivasi siswa lebih banyak dalam pembelajaran.

Chotijah \& Suparman (2017) mengemukakan bahwa terdapat indikator kesiapan guru dalam melaksanakan pembelajaran abad 21, yaitu: 1) kebutuhan guru akan bahan ajar alternatif, 2) kebutuhan guru akan penerapan pendidikan karakter dan skill abad 21. Oleh karena itu, guru dituntut mempunyai kreativitas untuk menyusun dan mengembangkan bahan ajar yang inovatif, variatif, menarik, dan sesuai dengan kebutuhan siswanya (Nurmita, 2017). Hal ini sejalan dengan Peraturan Menteri Pendidikan Nasional (Permendiknas) nomor 41 tahun 2007 tentang Standar Proses yang antara lain diharapkan guru dapat mengembangkan bahan ajar sebagai salah satu sumber belajar.

Fakta lain menunjukan bahwa guru masih mengalami kesulitan dalam melaksanakan pembelajaran matematika yang berorientasi pada kopetensi abad 21. Berdasarkan hasil survei terbatas guru-guru matematika di Kota Serang Banten, penyebab masalah tersebut sangat variatif, diantaranya adalah karena lemahnya pengetahuan dan kemampuan untuk merencanakan, melaksanakan, dan mengevaluasi hasil pembelajaran matematika yang berorientasi pada kompetensi abad 21. Mereka juga sulit memilih metode pembelajaran dan buku ajar yang berorientasi pada kompetensi abad 21. Menurut pengamatan penulis, buku ajar yang beredar pada saat ini masih bersifat praktis dan tidak memuat permasalahan yang berorientasi pada kompetensi abad 21. Buku ajar tersebut langsung dimulai dengan konsep matematika kemudian dengan contoh soal dan soal latihan tanpa 
mengunakan permasalahan untuk menemukan konsep matematika yang berorientasi pada kompetensi abad 21.

Berdasarkan permasalahan pada buku ajar yang beredar disekolah pada saat ini dan hasil survei di lapangan tentang analisis kebutuhan buku ajar matematika, maka perlu dikembangkan buku ajar matematika yang berorientasi pada kompetensi abad 21. Buku ajar yang berorientasi pada kompetensi abad 21 diharapkan dapat membantu guru menyelesaikan permasalahan yang sesuai dengan langkah-langkahnya, dan dapat digunakan sebagai bahan ajar yang mengaktifkan siswa. Sehingga siswa dapat memahami konsep matematika dan memiliki kecakapan berpikir abad 21. Contoh materi yang ada kaitannya dalam kehidupan sehari-hari siswa yang berorientasi pada kompetensi abad 21 adalah materi Pythagoras. Adapun tujuan penelitian ini adalah sebagai berikut:

1. Menghasilkan buku ajar matematika berorientasi abad 21 yang valid untuk pokok bahasan Pythagoras.

2. Menghasilkan buku ajar matematika berorientasi abad 21 yang praktis untuk pokok bahasan Pythagoras.

\section{METODE}

Dalam penelitian ini, peneliti menggunakan metode penelitian pengembangan (Research and Development). Penelitian pengembangan ini dirancang untuk memperoleh suatu produk buku ajar guru matematika SMP pada materi Pyhtagoras yang dilengkapi dengan LKS dan instrumen penilaian yang berorientasi pada kompetensi abad 21 . Menurut (Sugiyono, 2017) metode penelitian da pengembangan adalah metode penelitian yang digunakan untuk menghasilkan produk tertentu dan menguji keefektifan produk tersebut.

Prosedur penelitian yang akan ditempuh pada penelitian ini mengacu pada prosedur penelitian pengembangan Gall \& Borg. Gall \& Borg (2003) memaparkan sepuluh langkah pelaksanaan strategi penelitian dan pengembangan. Namun pada penerapan langkahlangkah pegembangan dalam penelitian ini disesuaikan dengan kemampuan dan kebutuhan peneliti. Maka langkah-langkah tersebut disederhanakan menjadi tujuh tahap penelitian, yaitu: 1) Analisis Kebutuhan, 2) Kemampuan Peneliti Sebagai Pengembang, 3) Produk yang Dikembangkan, 4) Konsep Produk, 5) Pengembangan Produk, 6) Uji Ahli, dan 7) Uji Coba. Dengan demikian, pada penelitian ini langkah-langkah metode penelitian dapat digambarkan pada gambar berikut ini:

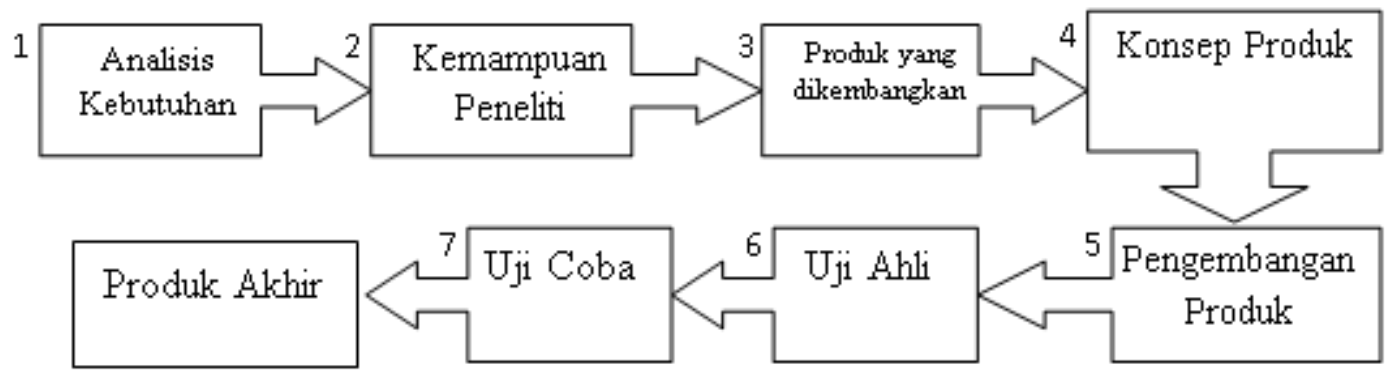

Gambar 1. Tujuh Langkah Penggunaan Metode Research and Development Model Borg \& Gall 
(1) Analisis kebutuhan: Analisis kebutuhan ini mencakup pengumpulan informasi yang meliputi kajian pustaka, pengamatan atau observasi kelas, dan persiapan laporan awal; (2) Kemampuan Peneliti sebagai Pengembang: Kemampuan dalam pengembangan produk untuk menjawab suatu kebutuhan merupakan hal penting agar produk yang tepat guna dapat terwujud. Namun, apabila dalam proses pengembangan produk ini terdapat keterbatasan kemampuan terkait dengan keahlian pengembangan produk yang berada di luar kemampuan peneliti, maka peneliti akan meminta pihak lain sebagai mitra untuk bekerja sama dalam pengembangan produk bahan ajar tersebut; (3) Produk yang dikembangkan: Produk yang akan dikembangkan dalam penelitian ini adalah berupa buku ajar matematika yang dapat mengoptimalkan guru dalam kegiatan pembelajaran untuk mencapai kompetensi abad 21; (4) Konsep Produk: Pada tahap ini kegiatan yang dilakukan adalah menentukan materi, tujuan dan perumusan kompetensi abad 21 yang nantinya akan dicapai setelah buku ajar digunakan; (5) Pengembangan: Pengembangan produk dibuat setelah adanya desain dan konsep produk. Peneliti mengembangkan produk bahan ajar berupa buku ajar matematika secara mandiri dengan bantuan Mc.Words. Dalam pembuatan produk ini materi dan desain pembelajaran matematika disesuaikan dengan tujuan untuk mencapai kompetensi abad 21; (6) Uji ahli: Validasi produk dilakukan dengan cara meminta bantuan beberapa pakar atau tenaga ahli yang sudah berpengalaman untuk menilai produk baru yang dirancang.

Dalam pengembangan produk ini ada tiga orang ahli yang dilibatkan diantaranya adalah ahli materi matematika, ahli bahasa, dan ahli media. Ahli materi menilai kualitas produk dari aspek isi materi; ahli bahasa menilai kualitas produk dari bahasa dan keterbacaan; sedangkan ahli media menilai kualitas produk dari aspek tampilan, dan (7) Uji Coba: Produk buku ajar matematika yang telah melewati tahap uji ahli, kemudian dilanjutkan pada tahap uji coba lingkungan. Uji coba buku ajar matematika ini dilakukan di lingkungan alami pengguna yaitu guru matematika SMP. Tujuan dari kegiatan uji coba ini adalah untuk mengetahui keterbacaan dan kepraktisan penggunaan buku ajar matematika tersebut di dalam kegiatan pembelajaran.

Berikut adalah hubungan antara buku ajar Pythagoras sebagai produk yang akan dikembangkan, kemampuan peneliti sebagai pengembang, dan kesiapan guru menggunakan buku ajar dalam proses belajar mengajar berdasarkan hasil analisis kebutuhan yang ditunjukkan pada gambar di bawah ini:

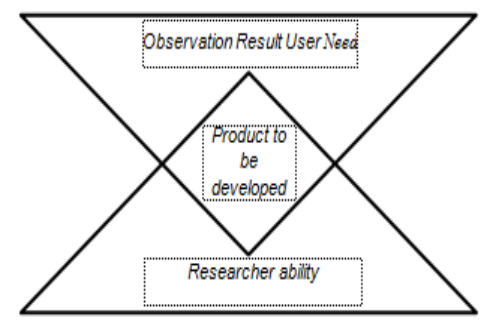

Gambar 2. Hubungan Produk yang Dikembangkan dengan Kemampuan Peneliti sebagai Pengembang dan Hasil Analisis Kebutuhan (Fathurrohman, 2014)

Jenis data yang diperoleh dari penelitian ini yaitu data primer yang diambil langsung dari lembaran validasi dari masing-masing validator buku ajar (ahli materi, ahli bahasa, dan ahli media) dan analisis kepraktisan buku ajar diambil dari hasil angket respon guru matematika SMP. Sedangkan instrument yang digunakan dalam pengumpulan data dalam penelitian pengembangan ini yaitu non tes, berupa angket. Angket digunakan untuk mengumpulkan data hasil review dari ahli materi, ahli bahasa, dan ahli media. Instrument 
kevalidan validasi dilakukan untuk mengetahui keabsahan buku ajar yang telah dirancang, yaitu buku ajar Pythagoras yang berorientasi pada kompetensi abad 21.

Teknik analisis data dalam penelitian ini dengan cara menganalisis data angket. Pengolahan data angket dilakukan dengan menggunakan data rating scale tipe numerical rating scale. Pada rating scale data mentah yang diperoleh berupa angka kemudian ditafsirkan dalam pengertian kualitatif (Riduwan, 2003). Penafsiran rating scale yang digunakan adalah $1=$ Sangat Kurang (SK), $2=$ Kurang (K), $3=$ Baik (B), $4=$ Sangat Baik (SB). Pada penelitian ini, penafsiran rating scale menggunakan skala empat. Selanjutnya penyusunan klasifikasi hasil angket menggunakan kategori persentase $(P)$ dihitung dengan menggunakan rumus berikut:

$$
P=\frac{S_{t}}{S_{\max }} \times 100 \%
$$

Dengan:

(Riduwan, 2003)

$\mathrm{P} \quad=$ Persentase jawaban

$\mathrm{S}_{\mathrm{t}} \quad$ = Jumlah skor total

$\mathrm{S}_{\max } \quad=$ Skor maksimal

Kemudian kategori persentase disusun melalui tabel sebagai berikut:

Tabel 1. Persentase Skor Jawaban

\begin{tabular}{cc}
\hline Persentase & Klasifikasi Bahan Ajar \\
\hline $80 \%<P \leq 100 \%$ & Sangat Baik (SB) \\
\hline $60 \%<P \leq 80 \%$ & Baik (B) \\
\hline $40 \%<P \leq 60 \%$ & Cukup (C) \\
\hline $20 \%<P \leq 40 \%$ & Tidak Baik (TB) \\
\hline $0 \% \leq P \leq 40 \%$ & Sangat Tidak Baik (STB) \\
\hline
\end{tabular}

(Riduwan, 2003)

Indikator keberhasilan dalam penelitian ini yaitu apabila buku ajar materi Pythagoras yang berorientasi pada kompetensi abad 21 telah memenuhi kriteria minimal dari uji ahli dan dapat berfungsi di lingkungan alami pengguna utama, dalam hal ini adalah guru matematika kelas VIII semester genap. Kriteria minimal yang dikatakan baik oleh tim puslitjaknov yakni apabila uji ahli terhadap bahan ajar tersebut telah mencapai $70 \%$ (Puslitjaknov, 2008).

\section{HASIL DAN PEMBAHASAN}

Prosedur pengembangan buku ajar materi Pythagoras yang beorientasi pada kompetensi abad 21 untuk guru SMP kelas VIII ini dilakukan dengan tujuh tahapan, yaitu: (1) Analisis kebutuhan, (2) Kemampuan peneliti sebagai pengembang, (3) Produk yang dikembangkan, (4) Konsep produk, (5) Pengembangan produk, (6) Uji ahli, dan (7) Uji coba lapangan. Berdasarkan penelitian pengembangan yang dilakukan, diperoleh hasil penelitian sebagai berikut: 


\section{Analisis kebutuhan}

Tuntutan pembelajaran matematika pada abad 21 diantaranya adalah peserta didik harus memiliki kompetensi berpikir tingkat tinggi. Kompetensi-kompetensi tersebut adalah kompetensi komunikasi (communication), kolaborasi (collaboration), berpikir kritis dan memecahkan masalah (critical thinking and problem solving), kreatif dan inovatif (creativity and innovation), yang saat ini disebut sebagai kemampuan 4C (Trilling \& Fadel, 2009). Sejalan dengan perkembangan teknologi dan informasi yang cepat dalam berbagai aspek kehidupan, ditemukan adanya kebutuhan untuk mengembangkan suatu produk yang dapat mengoptimalkan kesiapan guru matematika dalam menggunakan buku ajar matematika yang berorientasi pada kompetensi abad 21. Berdasarkan hasil survey terbatas kepada guru matematika di Kota Serang, menunjukkan bahwa guru masih mengalami kesulitan dalam melaksanakan pembelajaran matematika yang berorientasi pada kompetensi abad 21. Selain itu berdasarkan studi literatur dari beberapa buku ajar guru, belum ditemukan buku ajar guru yang mengarah pada kompetensi abad 21 (4C). Oleh karena itu dibutuhkan bahan ajar yang mampu menjembatani siswa dalam mengembangkan kemampuan abad 21 tersebut.

\section{Kemampuan Peneliti sebagai Pengembang}

Dalam mewujudkan produk tepat guna yang sesuai dengan hasil temuan pada analisis masalah, kemampuan peneliti dalam pengembangan merupakan hal penting agar produk yang tepat guna dapat terwujud. Dalam penelitian ini peneliti mengembangkan produk secara mandiri dengan bantuan aplikasi Mc.Word.

\section{Produk yang Dikembangkan}

Titik temu antara analisis kebutuhan dengan kemampuan peneliti sebagai pengembangan produk ini adalah produk yang dikembangkan. Dalam hal ini produk yang dimaksud untuk mengoptimalkan kesiapan guru dalam pembelajaran adalah bahan ajar matematika berupa buku ajar materi Pythagoras yang berorientasi pada kompetensi abad 21 untuk guru SMP.

\section{Konsep Produk}

Produk yang dikembangkan pada penelitian ini berupa buku ajar materi Pythagoras yang berorientasi pada kompetensi abad 21 untuk guru SMP. Buku ajar guru ini dilengkapi dengan Lembar Kegiatan Siswa (LKS) dan Instrumen Penilaian yang semuanya berorientasi pada kompetensi abad 21. Buku ajar yang dikembangkan disesuaikan dengan kurikulum dan karakteristik peserta didik.

Berdasarkan kurikulum yang telah ditetapkan yaitu kurikulum 2013 revisi tahun 2017, ada dua kompetensi dasar yang harus dikuasai siswa setelah belajar Teorema Pythagoras yaitu sebagai berikut.

Tabel 2. Kompetensi Dasar Aspek Pengetahuan dan Keterampilan Matematika Materi Teorema Pythagoras

\begin{tabular}{ll}
\hline \multicolumn{1}{c}{$\begin{array}{c}\text { Kompetensi Dasar Aspek } \\
\text { Pengetahuan }\end{array}$} & \multicolumn{1}{c}{$\begin{array}{c}\text { Kompetensi Dasar Aspek } \\
\text { Keterampilan }\end{array}$} \\
\hline $\begin{array}{l}\text { Menejelaskan dan membuktikan Teorema } \\
\text { Pythagoras dan Tripel Pythagoras }\end{array}$ & $\begin{array}{l}\text { Menyelesaikan masalah yang berkaitan } \\
\text { dengan Teorema Pythagoras dan Tripel } \\
\text { Pythagoras }\end{array}$ \\
\hline
\end{tabular}


Kompetensi abad 21 yang digunakan dalam pengembangan buku ajar ini adalah kompetensi 4C, yaitu : kompetensi komunikasi (communication), kolaborasi (collaboration), berpikir kritis dan memecahkan masalah (critical thinking and problem solving), kreatif dan inovatif (creativity and innovation). Soal-soal yang disajikan juga berupa soal konstektual yang mengarah kepada kompetensi abad 21.

\section{Pengembangan Produk}

Buku ajar Pythagoras dikembangkan dengan memperhatikan kesesuaian materi/isi, kesesuaian buku ajar dengan syarat didaktik, kesesuaian buku ajar dengan syarat konstruksi, kesesuaian buku ajar dengan syarat teknis, serta kesesuaian buku ajar untuk melatih kompetensi Abad 21. Secara garis besar, pengembangan buku ajar materi Pythagoras untuk siswa SMP kelas VIII semester 2 yang disajikan dalam sebuah buku terdiri dari tujuh bagian yaitu (1) cover bab, (2) penjelasan KI, KD, dan Indikator, (3) peta konsep, (4) mengenal tokoh, (5) isi bab dan lembar kegiatan siswa, dan (7) uji kompetensi.

\section{(1) Cover Bab}

Halaman cover bab meliputi urutan bab, judul bab, gambar yang merepresentasikan isi bab, dan kata kunci yang terkait dengan judul bab. Pada cover bab Teorema Pythagoras disajikan gambar konstruksi atap rumah di sebuah perumahan yang menggunakan rangka baja ringan. Pada kerangka atap rumah tersebut sebagian besar rusuknya tegak lurus terhadap rusuk yang lainnya. Konstruksi atap rumah atau gedung banyak menggunakan aplikasi teorema Pythagoras. Dengan teorema ini, memudahkan arsitek atau kontraktor untuk memperhitungkan seberapa banayak bahan dan biaya yang dibutuhkan dalam membangun rumah tersebut. Adapun cover Teorema Pythagoras diperlihatkan pada Gambar 3 (a).

(2) Penjelasan KI, KD, dan Indikator

Pada bagian ini dijelaskan Kompetensi Inti, Kompetensi Dasar, dan Indikator untuk materi Pythagoras sesuai dengan kurikulum yang berlaku yaitu Kurikulum 2013 yang telah direvisi. Tampilan penjelasan KI, KD, dan Indikator diperlihatkan pada Gambar 3 (b).

\section{(3) Peta Konsep}

Peta konsep disajikan untuk memudahkan pengguna buku dalam melihat alur setiap topik serta keterkaitan antar topik pada bab tersebut. Peta konsep yang disajikan meliputi nama bab, topik umum, serta topik-topik yang lebih khusus. Tampilan peta konsep bab Teorema Pythagoras diperlihatkan pada Gambar 3 (c).

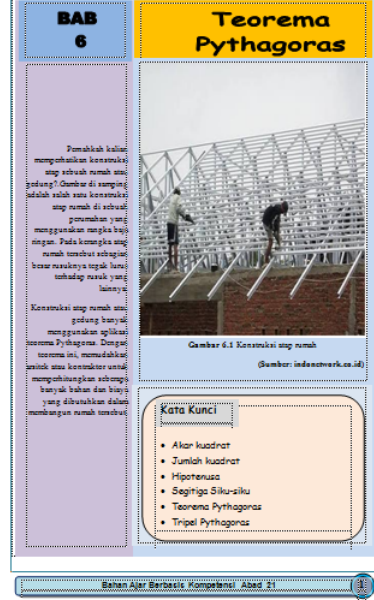

(a)

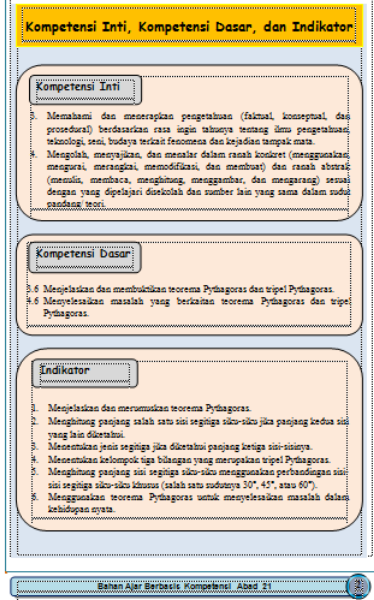

(b)

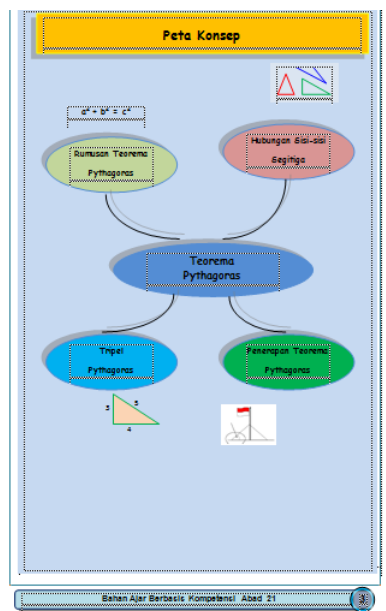

(c)

Gambar 3(a). Tampilan Cover Bab Teorema Pythagoras. Gambar 3(b). Penjelasan KI, KD, dan Indikator. Gambar 3(c). Peta Konsep Bab Teorema Pythagoras 
(4) Mengenal Tokoh

Pada bagian ini, ditampilkan foto Pythagoras dan diceritakan sekilas tentang perjalanan Pythagoras. Selain itu disajikan pula hal-hal yang bisa diteladani dari sosok Pythagoras.

\section{(5) Isi Bab dan LKS}

Pada materi Teorema Pythagoras, terdapat empat subbab yaitu Memahami Teorema Pythagoras, Jenis Segitiga Berdasarkan Panjang Sisi dan Tripel Pythagoras, Perbandingan Sisi-sisi Segitiga Siku-siku, dan Penerapan Teorema Pythagoras pada Soal Cerita. Teorema Pythagoras sebenarnya bukan materi yang baru dikenal oleh siswa SMP kelas VIII, karena di SD pernah dibahas ketika materi segiempat meskipun tidak rinci.

Subbab pertama Memahami Teorema Pythagoras diawali dengan penyajian tiga buah gambar yang didalamnya terdapat benda yang memilik sudut siku-siku. Masalah yang dimunculkan berdasarkan gambar tersebut adalah bagaimana cara untuk mengetahui bahwa siku pada suatu benda benar-benar yang disebutkan adalah siku-siku. Pada bagian ini diharapkan dapat menumbuhkan kompetensi abad 21 yaitu aspek kemampuan berpikir kritis dan kreatif.

Selain itu pada subbab satu disajikan juga Lembar Kegiatan Siswa untuk menumbuhkan kemampuan berpikir kreatif, serta untuk melibatkan pengetahuan siswa sebelumnya mengenai empat buah segitiga siku-siku yang disusun menjadi segiempat. Salah satu kesimpulan pada kegiatan tersebut adalah Teorema Pythagoras. Melalui penemuan terbimbing secara berkelompok, siswa dihantarkan untuk bisa membuktikan kebenaran Teorema Pythagoras.

Setelah menyelesaikan Lembar Kegiatan Siswa, setiap kelompok diarahkan untuk menyampaikan hasil diskusi tentang materi Memahami Teorema Pythagoras berupa kesimpulan berdasarkan hasil analisis secara lisan, tertulis, atau media lainnya. Setelah itu, berikan kesempatan kelompok lain untuk menanggapi. Hal ini diharapkan dapat menumbuhkan kemampuan komunikasi dan kolaborasi.

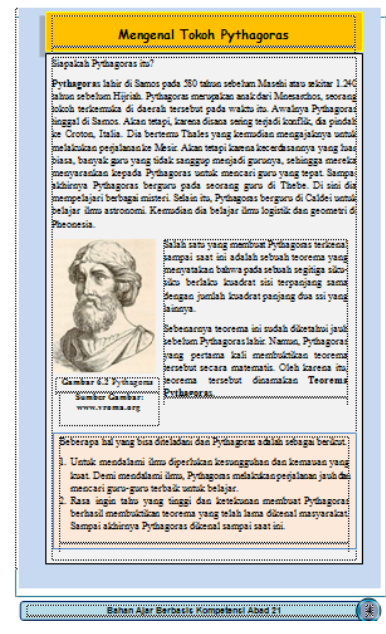

(a)

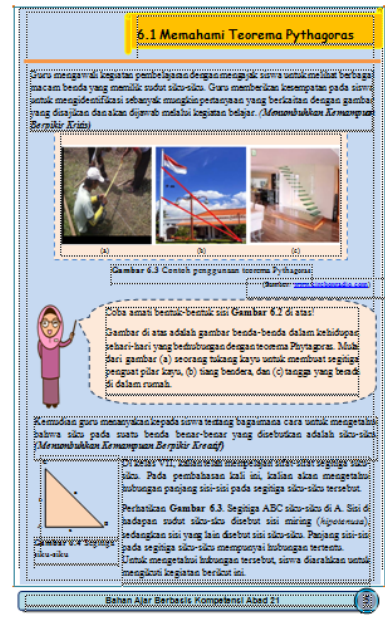

(b)

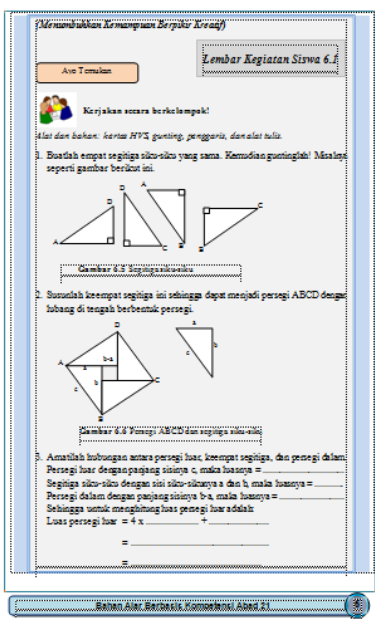

(c)

Gambar 4(a). Tampilan Mengenal Tokoh Pythagoras. Gambar 4(b). Pengantar Subbab satu. Gambar 4(c). Lembar Kegiatan Siswa Menemukan Konsep Teorema Pythagoras

Pada subbab kedua, dibahas mengenai Jenis Segitiga Berdasarkan Panjang Sisi dan Tripel Pythagoras yang dipecah menjadi tiga bagian subbab khusus lagi yaitu Kebalikan Teorema Pythagoras, Menentukan Jenis Segitiga, dan Tripel Pythagoras. Pada subbab kedua ini sama seperti pada subbab pertama yaitu tedapat langkah-langkah pembelajaran yang diarahkan untuk menumbuhkan kemampuan kompetensi abad 21. Terdapat Lembar 
Kegita Siswa juga disetiap subbab hkusus dengan tujuan mngarahkan siswa untuk menemukan konsep setiap subbab.

Pada subbab ketiga, dibahas mengenai Perbandingan Sisi-sisi Segitiga Siku-siku. Pada subbab ini diawali dengan pengajuan beberapa pertanyaan untuk mengarahkan siswa agar bisa menyimpulkan perbandinag sisi-sisi segitiga siku-siku. Pertanyaan tersebut diantaranya adalah: Bagaimana hubungan antar sisi pada segitiga siku-siku?. Dapatkah hubungan tersebut digunakan untuk mengetahui perbandingan sisi-sisi segitiga siku-siku khusus?. Bagaimana perbandingan sisi-sisi segitiga siku-siku khusus tersebut?

Pada subbab keempat, dibahas mengenai Penerapan Teorema Pythagoras pada Soal Cerita. Pada subbab ini, diawali dengan penyajian permasalahan dalam kehidupa seharihari yang penyelesaiannya menggunakan Teorema Pythagoras. Ilustrasi permasalahan yang disajikan adalah mengenai dua buah tiang bendera yang berdampingan dengan jarak tetentu dan tinggi yang berbeda. Dengan menggunakan konsep Teorema Pythagoras, siswa diharapkan dapat menghitung panjang kawat penghubung antara ujung tiang bendera tersebut.

Setiap subbab diberikan juga contoh soal yang dilengkapi dengan cara penyelesaian. Selain itu di akhir setiap subbab terdapat juga evaluasi (ayo berfikir). Bagian bahan ajar ini berisi soal berkaitan dengan subbab yang dibahas, yang mengacu pada indikator 4C. Penggunaan kata "ayo berfikir" dimaksudkan agar siswa merasa diajak oleh bahan ajar, tidak merasa diperintah, sehingga mereka mau mencoba menyelesaikan soal-soal tersebut. Salah satu contoh evaluasi ditunjukkan pada Gambar 4 (a).

\section{Uji Kompetensi}

Pada akhir bab disajikan uji kompetensi yang disajikan untuk melihat sejauh mana tingkat penguasaan siswa terhadap keseluruhan materi dalam bab tersebut. Uji kompetensi terdiri dari 5 soal pilihan ganda dan 3 soal isian. Selain soal yang langsung dibuat oleh penulis, terdapat soal-soal yang dikutip dari berbagai sumber (Ujian Nasional, soal olimpiade, soal PISA).

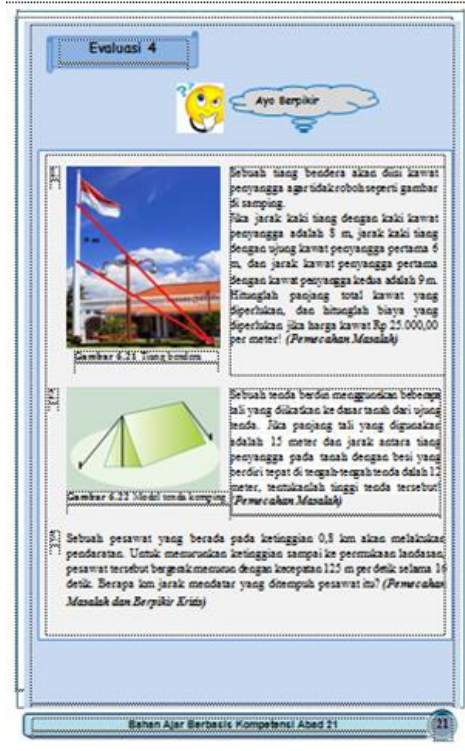

(a)

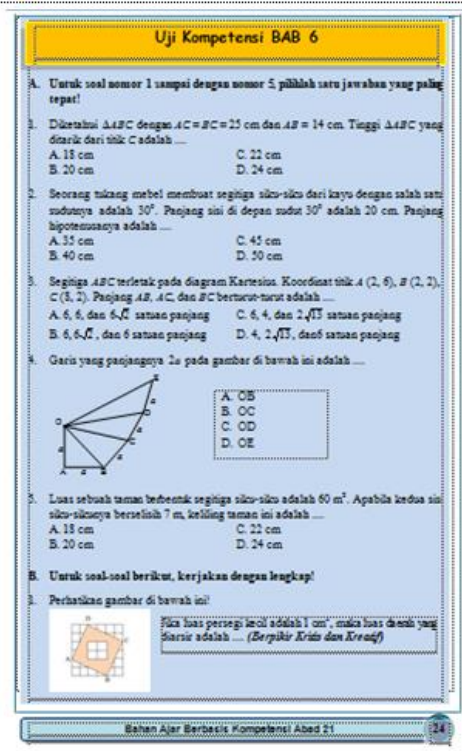

(b)

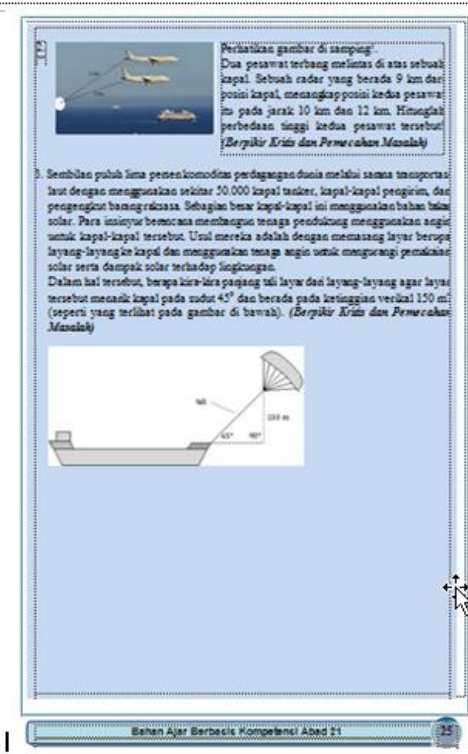

(c)

Gambar 5 (a). Soal Evaluasi Subbab. Gambar 5 (b) \& (c). Soal Uji Kompetensi

\section{Uji Ahli}

Buku ajar yang telah selesai dibuat, selanjutnya dievaluasi dan diuji kelayakannya melalui tahap validasi oleh para ahli. Tahap ini bertujuan untuk mengetahui apakah buku ajar Pythagoras tersebut layak atau tidak untuk diujicobakan. Ahli yang dilibatkan meliputi 
ahli materi matematika, ahli bahasa, dan ahli media. Berikut tabel hasil validasi uji ahli materi matematika, ahli bahasa, dan ahli media:

Tabel 3. Hasil Uji Validasi Buku Ajar Pythagoras oleh Ahli

\begin{tabular}{cccccc}
\hline No. & Aspek & Skor & Max & $\%$ & Kriteria \\
\hline 1 & Materi & 128 & 160 & 80,00 & Baik \\
\hline 2 & Bahasa & 51 & 52 & 98,08 & Sangat Baik \\
\hline 3 & Media & 101 & 124 & 81,45 & Sangat Baik \\
\hline
\end{tabular}

Berdasarkan hasil uji validasi yang dilakukan oleh ahli materi, ahli media, dan ahli bahasa ketiga ahli menyatakan bahwa produk yang dikembangkan layak digunakan dalam kegiatan pembelajaran matematika.

\section{Uji Coba Lapangan}

Tujuan dari kegiatan uji coba ini adalah untuk menilai kepraktisan buku ajar Pythagoras yang meliputi keterbacaan dan kepraktisan pengguna yang dilakukan oleh guru. Berikut tabel hasil uji coba lapangan:

Tabel 4. Hasil Uji Coba Lapangan

\begin{tabular}{cccccc}
\hline No. & Responden & Skor & Max & $\%$ & Kriteria \\
\hline 1 & Guru & 93 & 100 & 93,00 & Sangat Baik \\
\hline
\end{tabular}

Berdasarkan hasil uji coba lapangan yang dilakukan terhadap guru dan siswa menyatakan bahwa produk yang dikembangkan cukup praktis digunakan baik oleh guru.

\section{SIMPULAN}

Berdasarkan pembahasan di atas, maka dapat disimpulkan bahwa bahan ajar berupa buku ajar Pythagoras yang berorientasi pada kompetensi abad 21 untuk guru SMP kelas VIII yang dikembangkan termasuk kategori sangat baik dan layak menurut penilaian para ahli. Sehingga disarankan bagi guru matematika kelas VIII agar dapat menggunakan buku ajar Pythagoras yang berorientasi pada kompetensi abad 21 ini. Selain itu bagi peneliti lain disarankan untuk dapat mengembangkan buku ajar yang berorientasi pada kompetensi abad 21 pada materi lain.

\section{DAFTAR PUSTAKA}

Chotijah, H. Y., \& Suparman. (2017). Analisis Kebutuhan Pengembangan Buku Panduan Guru Implrmmtasi Lesson Study pada Pembelajaran Matematika Sedolah Dasar. In The 5th Urecol Procedding (pp. 920-925). Yogyakarta: UAD.

Fathurrohman, M. (2014). Metode Penelitian Pengembangan. Serang: Untirta Press.

Gall, M. D., \& Borg, W. R. (2003). Educational Research an Introduction (7th ed.). Boston: Allyn \& Bacon.

Khikmiyah, F., \& Midjan. (2016). Pengembangan Buku Ajar Literasi Matematika untuk Pembelajaran di SMP. Jurnal Silogisme, 1(2), 15-26. 
Mendikbud. (2016). Peraturan Menteri Pendidikan dan Kebudayaan Nomor 21 Tahun 2016 tentang Standar Isi Pendidikan Dasar dan Menengah, Pub. L. No. 21 Tahun 2016, 1. Indonesia.

Mendikbud. (2017). Model Silabus Mata Pelajaran SMP/ MTs. Jakarta.

Mendiknas. (2001). Petunjuk Teknis Pelaksanaan Penilaian Angka Kredit Jabatan Dosen, Pub. L. No. 36, 27. Indonesia.

Nurmita, F. (2017). Pengembangan Bahan Ajar SIswa dan Buku Guru Berbasis Matematika Realistik untuk Meningkatkan Pengetahuan, Sikap, dan Keterampilan Matematika Siswa Kelas VII SMP Al Karim Kota Bengkulu. Edu - Mat: Jurnal Pendidikan Matematika, 5(1), 86-98.

Puslitjaknov. (2008). Metode Penelitian Pengembangan. Jakarta: Tim Puslitjaknov.

Riduwan. (2003). Dasar-dasar Statistika. (P. D. Iswara, Ed.) (3rd ed.). Bandung: ALFABETA.

Sugiyono. (2017). Metode Penelitian Kuantitatif, Kualitatif, dan $R \& D$ (26th ed.). Bandung: Alfabeta.

Sungkono. (2009). Pengembangan dan Pemanfaatan Bahan Ajar Modul dalam Proses Pembelajaran. Jurnal Majalah Ilmiah Pembelajaran, 1(1), 1-13.

Susanto, H. (2013). Teknik Penyusunan Buku Ajar. In Penyusunan Buku Ajar (p. 16). Semarang: Universitas Muhamadiyah.

Trilling, B., \& Fadel, C. (2009). 21st Century Learning Skills. San Francisco: Jossey Bass.

\title{
The Development of Learning Material on Pythagoras Topic for Teacher Based on 21st Century Skills
}

\section{Ida Maryamah *}

Postgraduate Mathematics Education Program, Universitas Sultan Ageng Tirtayasa, Serang, Indonesia,*Corresponding Author, idamaryamah@gmail.com

\section{Nurul Anriani}

Postgraduate Mathematics Education Program, Universitas Sultan Ageng Tirtayasa, Serang, Indonesia,nurul_anriani@yahoo.co.id

\section{Maman Fathurrohman}

Postgraduate Mathematics Education Program, Universitas Sultan Ageng Tirtayasa, Serang, Indonesia, mamanf@untirta.ac.id

\begin{abstract}
The purpose of this study was to produce products learning material on pytagoras topic based on $21 \mathrm{st}$ century skill. This type of research is development research that covers seven steps, namely: needs analysis, the ability of researchers as developers, products developed, product concepts, product development, expert testing, and field trials. The validity of this product is obtained based on data of questionnaires from expert assessment, namely content experts, linguists, and media experts. Assessment of content experts reached a good category, linguists reached a very good category, and media experts reached a very good category. While the readability and practicality of learning material were obtained from questionnaire assessment data of mathematics teachers whose results reached a very good category. So it can be concluded that the product is suitable for use in mathematics learning activities.
\end{abstract}

Keywords: Mathematics Learning Materials, Pythagoras Topic, 21st Century Skills

Received October $31^{\text {st }}, 2018$

Revised November $16^{\text {th }}, 2018$

Accepted November $19^{\text {th }}, 2018$

Pengembangan Bahan ajar Materi Pythagoras yang Berorientasi... (Maryamah, Anriani., \& Fathurrohman) 